Ruth B. Bottigheimer

\title{
Hannā Diyāb’s “A Sultan of Samarcand”, an Eleventh-Century Old Georgian St. George Legend, and the Construction of an Early Modern Fairy Tale
}

\begin{abstract}
Of the sixteen stories Hannā Diyāb told Antoine Galland to help the elderly scholar complete his 12-volume Mille et Une Nuits (1704-1717) six were omitted. This article examines one of the six discarded tales, "A Sultan of Samarcand". Rediscovered by Hermann Zotenberg in the late 1880s, translated soon thereafter into English by Richard Burton, it was contextualized historically as a product of Eastern Christian narrative tradition by Joseph Szövérffy in 1956 and categorized typologically by him within the Aarne-Thompson tale-type index, as it then existed. Kevin Tuite's recent research and translation of an eleventhcentury Georgian religious legend supports my hypothesis that the Christian St. George legend supplied the story's core episode. The role of reference works is introduced inter alia to illuminate their role within knowledge creation in general and in the discontinuities of "A Sultan of Samarcand" research in particular.
\end{abstract}

Keywords: Arabian Nights, Hannā Diyāb, St. George legend, fairy tale history and theory, "A Sultan of Samarcand", research on research

\section{Introduction ${ }^{1}$}

In 1709 Hannā Diyāb (c1679/80-after 1764), a Christian Arab from Aleppo, a Syrian entrepot in the Ottoman empire, told Antoine Galland (1646-1715) the magic-filled tale, "A Sultan of Samarcand" to help the elderly Galland complete his translation of Mille et Une Nuits. ${ }^{2}$ Galland omitted this story and all mention of the narrator from the Nights, effectively

1 I would like to thank Carol Marburger, Johannes Thomann, Kevin J. Tuite, Hans-Jörg Uther, and Jan M. Ziolkowski for their friendly and generous collegial support.

2 Bauden 2011: 49.

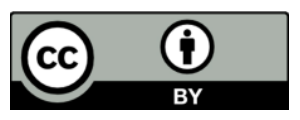


erasing both Diyāb and "A Sultan of Samarcand" from Nights scholarship for more than 150 years. When Hermann Zotenberg (1836-1894) transcribed the story from Galland's diary and published it, untitled, in 1887 and again in 1888, Richard Burton (1821-1890) immediately translated it into English, titled it "The Story of the Three Princes, the Genius Morhagian, and his Daughters", and associated it with the Arabian Nights by placing it in the final volume of his Supplemental Nights to the Book of the Thousand Nights and One Night in 1888. ${ }^{3}$ Widely ignored for another 60 years, Diyāb's story drew the attention of Joseph Szövérffy (1928-2001) in the 1950s. He viewed "A Sultan of Samarcand", as belonging to Antti Aarne and Stith Thompson's tale-type 301, and theorized a previously unrecognized Eastern sub-type 301C, ${ }^{4}$ a concept that this article further develops and that are supported by Kevin J. Tuite's forthcoming studies of an eleventh-century Old Georgian manuscript (Jer. Geo. 2), the earliest medieval Eastern Christian St. George religious legend, which survives at the core of the early modern secular fairy tales of tale-type 301. The article concludes with a hypothesized historical development of "A Sultan of Samarcand" as it circulated in southwestern Asia and southeastern Europe in the $19^{\text {th }}$ and $20^{\text {th }}$ centuries, from earlier tellings of which Diyāb's "A Sultan of Samarcand" derives. ${ }^{5}$

3 Burton 1886-1888: N.B. Conventionally, Burton's Supplemental Nights are referred to as consisting of 6 volumes. But the first edition that I have used consists of 7 volumes of Supplemental Nights more or less equal length and bears the notation "VOLUME VII" on its title page and spine. The first volume of this edition of Supplemental Nights is dated "December 1, 1886" at the end of Burton's "Translator's Foreword" (vol. 1. [vii]-viii). The final volume bears no date but is dated 1888 by OCLC.

4 Szövérffy 1956: 89-124.

5 The story is discussed in entered in "The Three Princes and the Genius Morhagian and His Daughters, 417 Story of the (Burton from the Chavis manuscript)" in The Arabian Nights Encyclopedia (Marzolph-Van Leeuwen 2004: 417.). The article attribute "A Sultan of Samarcand" to the Chavis manuscript of "Aladdin" via Richard Burton, whereas Burton took his text from Zotenberg, who reproduced the story from Galland's journal recording of Hannā Diyāb's telling. Zotenberg wrote of the story, "que l'illustre orientaliste avait recueillis de la bouche du Maronite Hannā" (Zotenberg 1888: 53.). Zotenberg did not include the title that heads the story, "Un Sultan de Samar" (Galland [1709] 2011: 347.); Burton titled his translation of Zotenberg's transcription "Story of the Three Princes and the Genius Morhagian and his Daughters" (Burton 1886-1888: 363.), and a reading of the opening paragraph indicates that Burton's English text is a relatively free translation of Zotenberg's French transcription, while Zotenberg's transcription follows Galland's journal entry as closely as it was possible for him to do, before the existence of a critical edition, but adding some diacriticals and substituting “j” for " $i$ ". 
Hannā Diyāb's $A$ Sultan of Samarcand...

The history of "A Sultan of Samarcand"6 is one of witting and unwitting erasures. Antoine Galland replaced the real Hannā Diyāb as narrator by giving to the fictive Shahrazad stories that he told and that Galland took into his iconic collection. He also excluded "A Sultan of Samarcand" from his iconic collection. Hermann Zotenberg restored the story, but omitted its title, probably because the story's opening words repeat it. The absent title provided Richard Burton with a space he filled with a typically Victorian malecentered title that placed auxiliary brothers ahead of the sisters whose three stories occupy far more narrative space than do those of the brothers. The pathbreaking scholarship of Joseph Szövérffy has been displaced by shifting understandings of the Finnish historico-geographic methodology, and by consequent shifts in its influential research tool, the tale-type indexes that began with Antti Aarne and are now represented by the 2004 revision by Hans-Jörg Uther. Finally, the creation of knowledge embodied by encyclopedic reference works has prolonged the erasures begun by Galland: the first documented telling of "A Sultan of Samarcand" by Hannā Diyāb is displaced by a focus on the three princesses portion of the tale in the Enayklopädie des Märchens," while The Arabian Nights Encyclopedia credits authorship of "A Sultan of Samarcand" to a known forger, Dom Chavis. ${ }^{8}$ Telling "A Sultan of Samarcand" story in detail in the article that follows illuminates three centuries of both intent and accident.

"A Sultan of Samarcand" is one of sixteen stories that Hannā Diyāb, visiting Paris from the Ottoman Empire, told Antoine Galland in late May 1709. He had already contributed "Aladdin" to Galland's collection and would soon add "Ali Baba and the Forty Thieves". Diyāb told Galland sixteen stories in May and June that year, of which Galland used ten to complete his collection; he did not include the gripping yet puzzling "A Sultan of Samarcand". Thereafter Diyāb's telling languished unknown on the pages of the diary in which Galland had recorded it. Here is the story in brief:

The Sultan of Samarcand grants a wish to each of his three sons. The oldest prince chooses to build a fancifully constructed chamber, but during the first night he spends there, a jinni named Morhagian bursts in, announces that the chamber lies atop the palace of one of his daughters. He therefore reduces it to

6 In his journal Galland headed the story "Un Sultan de Samar", omitting "cande", apparently because of a problem with his pen (Galland [1709] 2011: 347).

7 Puchner 2002: 1363-1369.

8 Marzolph-Van Leeuwen 2004: 417. 
dust and then flees with the prince in pursuit and disappears down a well. These events are subsequently repeated when the middle and youngest princes have similarly fanciful chambers built. The youngest, Badi al-Zaman, manages to wound the fleeing monster.

The brothers try to go down the well, but only Badi al-Zaman, is able to pass through the intolerable heat of its middle section to reach the bottom. There a passageway leads to an underground palace, where the jinni's eldest daughter detains him for forty delightful days before sending him to the middle sister. After another forty days, the prince arrives at the palace of the youngest sister, Fattane, who proposes marriage ${ }^{9}$ and then entertains him for another forty days. Badi al-Zaman, who still wishes to vanquish the jinni, goes on a hunger strike to force Fattane, to reveal the jinni's vulnerability. With that knowledge Badi alZaman locates Morhagian and kills him with a single stroke of the jinni's sword.

Badi al-Zaman then sends the three princesses up the well to his waiting brothers, who, seeing the youngest princess's extraordinary beauty, abandon him below in the hope that one of them can marry her himself. Fattane, however, calls down to Badi al-Zaman that he should wait until Friday, when six bulls will appear, three red and three black. He must mount a red one, which will return him to the world above.

On Friday, Badi al-Zaman is forced onto the back of a black bull, which plunges seven times deeper into the earth, where an old woman informs him that a monster has sealed off the kingdom's water supply except during the time each week when he devours a sacrificial victim. This week's victim, the king's daughter, is awaiting her death. Badi al-Zaman goes to her; she warns him away; he stays, kills the monster, restores the water supply, and frees the princess. She secretly marks his shoulder with blood before returning to her father, who wishes to give her in marriage to the hero who has saved her. When Badi al-Zaman declines his offer, the king first threatens him with death, but then drives him away as a fool.

In subsequent wanderings, Badi al-Zaman kills a giant serpent that is about to eat a nest full of baby rukbs, after which he asks the grateful parent to return him to the world above. The rukb father agrees, instructing Badi al-Zaman to feed him a sheep's quarter each time he gives a signal until they reach the upper world. When the meat runs out, Badi al-Zaman feeds the rukh with fat from his own leg, which the rukb later restores.

Having returned to his father's kingdom, Badi al-Zaman disguises himself as a tailor's assistant, uses magic to reveal himself to the three sisters, kills his treacherous older brothers in jousts, and marries Princess Fattane with his father's blessing.

9 A motif repetition from Diyāb’s tale No. 8: "Prince Ahmed and Pari Banou", which Diyāb had told Galland a day earlier. 
Hannā Diyāb's $A$ Sultan of Samarcand...

\section{A Perplexing Story and Discontinuous History of Research}

There are parallel worlds in The Arabian Nights ("Jullanar of the Sea"), in seventeenth-century French fairyland fictions, and in Diyāb's "Aladdin" as well as his "Prince Ahmed and Pari Banou". But an underground realm reached by the hero's plunging seven times deeper into the earth and carried against his will by a wrong-colored animal is alien to every narrative tradition with which Diyāb has to date been associated - French, Italian, Hebrew, Arabic and/or Garshbuni. ${ }^{10}$ That kind of journey to an ultra-underworld is alien to fairy tale tradition in Europe, as is a princely dragon slaying without a consequent wedding.

Because Galland left Diyāb's "A Sultan of Samarcand" unpublished in his Arabian Nights collection Mille et Une Nuits. Contes Arabes (12 volumes, Thousand and One Nights. Arab/Arabian/Arabic Tales, 1704-1717), it lay forgotten in his journal in France's Bibliothèque nationale for nearly two hundred years. ${ }^{11}$ Only in the 1880s did Hermann Zotenberg discover the journal and transcribe Hannā Diyāb's 23 May 1709 story. ${ }^{12}$ When his transcription was published in an 1887 article and as a book in 1888,13 it captured the attention of Richard Burton, then in the final stage of completing the Book of $A$ Thousand Nights and One Night (1885-1886) by augmenting its ten volumes with the multi-volume Supplemental Nights. He was at work on the final volume of the Suplemental Nights when he discovered, and immediately translated, Zotenberg's transcription of Diyāb's story and inserted it into the collection's final volume.

The newly discovered "A Sultan of Samarcand" generated less interest than one might expect, since a near mania for Nights completeness in the late $19^{\text {th }}$ and early $20^{\text {th }}$ centuries drove searches for, and a corresponding production of Nights stories (which Burton's Supplemental Nights exemplifies) ${ }^{14}$ in addition to the then-current fascination with great men and heroic, and

10 Bottigheimer n.d.; Bottigheimer 2020; Bottigheimer 2019; Bottigheimer 2014a; Bottigheimer 2014b: 60-61.

11 Galland's journal together with his personal library was in all likelihood transferred to the Bibliothèque Royale after his death.

12 Galland's journal for 1708-1709 is now available in the critical edition prepared by Frédéric Bauden and Richard Waller.

13 Zotenberg 1888: 53-61.

14 It is worth noting that my copy of Burton's Nights still had many uncut pages, including those for the "A Sultan of Samarcand" more than 130 years after its initial publication. 
Ruth B. Bottigheimer

especially dragon-killing figures, a late example of which was Joseph Campbell's 1949 Hero With a Thousand Faces. 15

\section{Reference Works and Scholarship}

At the turn of the $20^{\text {th }}$ century the Kinder- und Hausmärchen (Children's and Household Tales) of Jacob and Wilhelm Grimm was the foremost reference point in the study of folk narrative and fairy tales. Beginning with its First Edition (2 vols., 1812, 1815) the Grimms had listed and described each tale's then-known historical and geographical counterparts in Germany, Europe, and beyond. ${ }^{16}$ The Grimms' 1856 Volume 3 provided the template for Johannes Bolte and Jirí Polívka's invaluable 5-volume Anmerkungen zu den Kinderund Hausmärchen der Gebrüder Grimm (1913; rpt. 1963), which vastly expanded the number of documented fairy tales related to those in the Grimm collection. In the case of this tale, the Grimms had included it as the fifth tale in the second volume of their First Edition, "Dat Erdmänneken", a dialect tale from the Paderborn area. To the Grimms' limited number of variants from German-speaking areas, Bolte and Polívka added scores of additional related tales from all areas of Europe. ${ }^{17}$

A reference work central to folk narrative research and published three years before Bolte and Polívka's Anmerkungen, Antti Aarne's Verzeichnis der Märchentypen (1910), classified tales according to their content and plot. In 1928 Stith Thompson translated Aarne's Verzeichnis into English as Types of the Folk-Tale and added significantly to its listings. Thompson augmented this research tool with his Motif-Index of Folk-Literature, which appeared in 6

15 In the same period, which coincided with the "Great Man" thrust of contemporaneous cultural values and historiography, tale-type 300 The Dragon Slayer preferentially attracted scholars' attention. As an apparent Ur-tale-type, Aarne-Thompson 300 (now ATU[ther] 300 in Uther 2004a 174.), with its monster-slayer hero marrying the intended royal victim at the end, was dominant.

16 The Grimms' scholarly apparatus was contained in volume 3, which appeared in 1856, while the tales in volumes 1 and 2 of the Final Edition were published in 1857.

17 Bolte-Polívka 1913: 297-318. Grimms and Grimm 1815: ix. In subsequent editions, "Dat Erdmänneken" was numbered KHM 91. The Grimms understood it and the Cologne variant they described as contemporaneous expressions of ancient Germanic mythology (xi-xii). The Grimms' contemporary Ludwig Bechstein also included several tales of this type, but his collection never gained scholarly prestige as had the Grimms' Kinder- und Hausmärchen and thus played no role in the development of reference literature. 
Hannā Diyāb's $A$ Sultan of Samarcand...

volumes from 1932 to 1936. The Bolte-Polívka, Thompson, and AarneThompson reference works continue to support and steer folk narrative and fairy tale research in the $21^{\text {st }}$ century, with the tale-type catalog newly revised by Hans-Jörg Uther in 2004.

In the Aarne-Thompson Types of the Folk-Tale the first listing among "Tales of Magic" was AaTh 300 The Dragon-Slayer. The next, AaTh 301, also involved dragon-slaying, but the dragon-slaying component was set within a different adjunct plot that involved three princesses. It was this tale-type, AaTh 301 The Three Stolen Princesses that was similar to Diyāb's "A Sultan of Samarcand".

In the early 1950s Joseph Szövérffy encountered an 1886 mention ${ }^{18}$ of St. George in connection with a Greek fairy tale recorded by Johann Georg von Hahn (1811-1869). ${ }^{19}$ Having completed a study of saint figures in folk narrative in 1948, Szövérffy was sensitized to and interested in the concept of a character in a fairy tale being rooted in the figure of a known saint such as St. George. Consequently, he sought out the large number of stories related to the Greek tale published by Hahn that had been catalogued within taletype 301 The Three Stolen Princesses. ${ }^{20}$ At that time, the Aarne-Thompson taletype catalog divided 301 into two differing European geographical areas, A and $\mathrm{B}$, each with slightly different tellings of the tale-type.

In reading the AaTh 301 tales, Szövérffy discerned a third group that he designated 301C, because in his view, they shared a distinctive set of the narrative components identified by Bolte and Polívka as A through F.21 Szövérffy applied the formula $\mathrm{B}^{2}-\mathrm{D}-\mathrm{E}^{1}-\mathrm{F}$ to these tales, which he noted contained no "unusual features and elements" but differed from AaTh 301A and AaTh 301B. Moreover, when he mapped the incidence of these tales he saw that "most of the versions of this $\left[\mathrm{B}^{2}-\mathrm{D}-\mathrm{E}^{1}-\mathrm{F}\right]$ type come from Eastern Europe, Asia Minor, and the area surrounding the Mediterranean"22.

For Szövérffy, the geography of the distribution of the 301C sub-type he proposed implied historical routes of origin and dissemination ${ }^{23}$ and he

18 Child 1886: 509.

19 Szövérffy 1956: 89; von Hahn 1864: 49-52.

20 The tale-type was then denominated AaTh 301 in reference to the tale-type catalogue's chief organizers and authors, Annti Aarne (1867-1925) and Stith Thompson (1885-1976). In 2004 Hans-Jörg Uther (1944-) revised the catalogue, and tale-type numbers bear the preceding designation ATU. The contents of this note are well known to folk narrativists, but I have included the information for scholars outside that discipline.

21 Bolte-Polívka 1913: 297-318.

22 Szövérffy 1956: 95.

23 Szövérffy 1956: 90. 
Ruth B. Bottigheimer

lamented the absence of datable texts. Nonetheless, in the case of his newly proposed sub-type $301 \mathrm{C}$ his mapped geographical distribution ${ }^{24}$ shows the tale-type spreading from Cappadocia north northeast into the south Caucasus; eastward through Armenia, Iran, and beyond; south through Turkey, Syria, Jordan, and beyond; and westward through Turkey to Greece. Earlier scholars, he noted, had perceived a geographical divide but hadn't recognized that it might be significant. ${ }^{25}$ Szövérffy, who knew Diyāb's 1709 "A Sultan of Samarcand" from Zotenberg's publication, recognized that it fit neatly into the $\mathrm{B}^{2}-\mathrm{D}-\mathrm{E}^{1}-\mathrm{F}$ group, ${ }^{26}$ and linked it and other $\mathrm{B}^{2}-\mathrm{D}-\mathrm{E}^{1}-\mathrm{F}$ tales to Eastern versions of the tale and to Eastern Christian legends of St. George. It is worth mentioning that in Szövérffy Eastern B2-D-E1-F group, St. George overcame the dragon in Cappadocia, the saint's homeland, whereas the thirteenth-century Legenda aurea compiled by the Genoese archbishop Jacob da Voragine (c 1230-1297 or 1298) placed St. George's dragon killing in Libya. ${ }^{27}$ Szövérffy also identified three of the Eastern story elements - the three underground sisters, the hero's saving a bird's young by killing a serpent, and the hero's being flown by the nestling's parent to the upper world - as tenacious elements within the 301C sub-type that he proposed.28 These three episodes also form an integral part of Diyāb's "A Sultan of Samarcand", and thus tie his story even more tightly to the same Eastern group.

In his conclusion, Szövérffy explicitly declared that his ability to draw reliable historical conclusions was impeded by the fact that all of the story documentation with which he (and by implication Aarne, Bolte, Polívka, and Thompson) had worked were stories that had been documented only

24 Szövérffy 1956: 115.

25 Szövérffy 1956: 95.

26 Szövérffy 1956: 93. To reach this conclusion, Szövérffy had to sort through masses of narrative material. One stands in awe of the gifts and skills that led him so surely to his conclusion, a mix of "Intuition und wissenschaftlich korrekter Arbeitsweise" ZiolkowskiBuschhausen 2002: 5.

27 Kevin J. Tuite has investigated an eleventh-century Old Georgian legend of St. George (MS Jer Geo 2 ) philologically and intertextually, and I consulted him about the extent and timing of scholarly knowledge about this early Eastern Christian St. George religious legend. He replied, "As far I know, the existence of the eleventh-century Old Georgian version of the princess-and-dragon legend would have been known to at most a small circle of scholars. The manuscript Jer Geo 2 had been studied by Georgian philologists in the late $19^{\text {th }}$ century, and the legend is listed in a catalogue from 1923. It was not until Privalova's 1977 book, however, that a summary of the Old Georgian version of the legend was made more widely available" (Tuite e-mail 6 April 2021).

28 Szövérffy 1956: 96-103. 
Hannā Diyāb’s $A$ Sultan of Samarcand...

recently, that is, in the $19^{\text {th }}$ and $20^{\text {th }}$ centuries. ${ }^{29}$ In this respect, Diyāb's "A Sultan of Samarcand" was and is a precious and datable narrative relic from the early $18^{\text {th }}$ century.

Overall, ${ }^{30}$ Szövérffy concluded that the entire tale-type 301 had arisen in the East in the form of the $\mathrm{C}$ variant and had then spread to the West. There were, however, narrative countercurrents, with a local west-to-east movement, especially from Greece into (earlier) Byzantine and/or (later) Ottoman Turkish areas.

Since the article's publication in 1956, Szövérffy's "modest" proposals and "scattered notes", as he termed his discursive presentation, has anticipated contemporary attention to "the importance of local and regional surveys", 31 but little or no attention has been paid to Diyāb's "A Sultan of Samarcand". In fact, in the more than 130 years that have passed since Hermann Zotenberg and Richard Burton returned Diyāb's telling of "A Sultan of Samarcand" to scholarly and public attention, Szövérffy's article, "From Beowolf to the Arabian Nights" is the sole sustained investigation touching on his story. At most, it is listed as one of Diyāb's sixteen tales, as in a recent Brazilian doctoral dissertation ${ }^{32}$ or with its constituent words implicitly scrutinized in a recent translation, ${ }^{33}$ but the tale has received little or no attention as a tale. Szövérffy's article has suffered a similar fate, with his proposal to establish a new sub-type, 301C, disappearing, as views about tale-type classification have changed. ${ }^{34}$

\section{An Eleventh-Century Old Georgian Religious Legend: St. George and the Dragon}

In a mark of our times, a category-driven internet process providentially delivered the text of a conference talk by Kevin J. Tuite, a University of Montreal specialist in anthropology and Old Georgian linguistics, to my

29 Szövérffy 1956: 115.

30 Szövérffy 1956: 95.

Szövérffy 1956: 117.

32 Codenhoto 2007: 43.

33 Marzolph-Duggan 2018a: 147-153.

34 Uther 2004a: 179. In the appendices of volume 3, Uther lists 301B and C as "Discontinued Types" (Uther 2004b: 8.), whose elimination he explains as a removal of Thompson's sub-types, which were "limited to restricted regions" (Uther 2004a: 12). 
computer screen. ${ }^{35}$ Its title, "The Old Georgian version of the miracle of St. George, the princess and the dragon", suggested relevance to Szövérffy's postulated Eastern, that is, southwest Asian and southeast European AaTh tale-type 301C. At that moment in the 2020/2021 year of the Covid-19 pandemic, internet connectivity fortuitously mitigated scholarly isolation. It also made it possible to have an electronic conversation about dating the spread of an Eastern Christian St. George-and-the-dragon narrative that predated Jacob da Voragine's St. George in the Golden Legend by more than two centuries. Tuite generously shared his expertise, explaining that only "specialists in Old Georgian philology" would have known of the eleventh-century Old Georgian St. George ms Jer Geo 2 in the 1950s, a time when "the oldest version of the legend known to scholars [...] would have been the twelfthcentury Greek ms studied by Aufhauser"36.

In this article, I focus solely on the contents of the eleventh-century religious legend treated in Tuite's philologically and historically rich paper, because its narrative illuminates important perspectives on the history of Diyāb's "A Sultan of Samarcand" and provides a date for a critical moment in the historical development of the fairy tale he told in May 1709. The eleventh-century legend, paraphrased and abbreviated below from Tuite's translation, begins by establishing the religious legend's time, place, characters, and situation:

Before St. George's martyrdom, the pagan King Selinos in the town of Lasia, angered God by persecuting Christians. Therefore, He sent into a nearby lake a dragon that devoured the people. ${ }^{37}$ The king and his people agreed to sacrifice their children one by one to appease the dragon. ${ }^{38}$ When the king had to sacrifice his only child, a daughter, he uttered a lament for the wedding and motherhood she would never have. ${ }^{39}$ Thwarted in his effort to redeem her life for money, ${ }^{40}$ and ignorant of God's plan for St. George to produce a miracle in his Cappadocian homeland, the king set her out for the dragon. ${ }^{41}$

35 The conference, "Sharing Myths, Texts and Sanctuaries in the South Caucasus" took place at the University of Regensburg in February 2020.

36 Tuite e-mail 6 April 2021; "Aufhauser" refers to a 1911 study of St. George dragon miracles discussed by Tuite n.d.a; Tuite n.d.b.

37 Tuite n.d.b 1-10.

38 Tuite n.d.b 11-21.

39 Tuite n.d.b 22-34.

40 Tuite n.d.b 35-40.

41 Tuite n.d.a 45. 
Hannā Diyāb’s $A$ Sultan of Samarcand...

When St. George encountered the weeping princess at the lake's edge, she tried to send him away, ${ }^{42}$ but after hearing her story, ${ }^{43}$ he reassured her. Learning that the people served Herakles, Apollo, Skamander, and Artemis, he asked God to perform a miracle by making the dragon submit to him (George). ${ }^{44}$ The dragon appeared, the maiden cried out, St. George made the sign of the cross over the dragon, prayed, and the dragon fell before him. ${ }^{45}$

Binding the dragon with the maiden's belt, he had her lead it toward the city, a great miracle in the eyes of the people. George credited God with the miracle and said that if the people would believe in Christ the true God, he would "make the dragon die" 46 . On their acceptance of Christianity, St. George killed the dragon and returned the girl to her father the king. ${ }^{47}$ Bishop Alexander baptized 45,000 people over fifteen days, and a temple was built "for the glory of God and to honor St. George", at whose completion the saint "showed another wonder" and "brought forth a healing spring" and produced "many other glorious wonders." 48

The legend continues with two further episodes:

On his homeward path, St. George met a short-statured demon with a staff in his hands, who spoke "peacefully", challenging him to prove his holiness. ${ }^{49}$ St. George drew a circle around him, made the sign of the cross, learned that the demon had been present at the Creation, but was later expelled from Heaven. The demon pleaded not to be sent to Hell, ${ }^{50}$ but St. George, who called on God to destroy him, made the sign of the cross in front of a "very large rock" that then opened up. St. George threw the demon into "the hole of fire", afterwards closing the rock and leaving the demon to "suffer for eternity" 51 .

The legend closes with a glorification of St. George, Jesus, and God. ${ }^{52}$

42 Tuite n.d.b 46-53.

43 Tuite n.d.b 54-68.

44 Tuite n.d.b 69-81.

45 Tuite n.d.b 82-90.

46 Tuite n.d.b 91-101.

47 Tuite n.d.b 102-104.

48 Tuite n.d.b 105-115.

49 The staff and staff-bearing of this demon recall the cudgel-bearing dwarfish NEM, who appeared in Hannā Diyāb's tale No. 8: "Prince Ahmed and Peri Banou", the story he told just prior to tale No. 9: "A Sultan of Samarcand".

50 Tuite n.d.b 116-128.

51 Tuite n.d.b 129-133.

52 Tuite n.d.a 134. 
One can imagine the eleventh-century legend of St. George having been created in order to associate a healing spring with a newly venerated dragonkilling saint. After all, St. George, had only relatively recently taken on the dragon-killing feat previously attributed to St. Theodore. The myth itself had, moreover, belonged to the same Greek mythology of Perseus and Andromeda that provided the deities worshiped by the princess's father in the eleventhcentury legend. ${ }^{53}$ There may well have been shrines to St. George in the Cappadocian reaches of the Byzantine Empire in the $11^{\text {th }}$ to the $16^{\text {th }}$ centuries, an area and a period from which St. George images survive. That would be consistent with the existence of medieval shrines specific to St. George where such a legend would have been maintained and propagated through centuries as a religious text.

\section{The Old Georgian Religious Legend, Hannā Diyāb's Fairy Tale, and the Evolution of a Religious Legend to a Secular Fairy Tale}

We recognize the St. George legend's plot in secularized form - prince, dragon, princess - at the center of Hannā Diyāb's 1709 "A Sultan of Samarcand", as well as in the several closely related fairy tales identified by Szövérffy as tale-type 301C. Just as in the eleventh-century legend, a hero saves a princess from a dragon, but does not marry her. Because the hero's life-threatening exploit so regularly leads to marriage in classic fairy tale narratives, let us attempt a Gedankenversuch, a thought experiment, as a way of understanding why that critical plot element in the religious legend remained unchanged in tale-type 301, and specifically in the case of Szövérffy's proposed sub-type 301C, to which he assigned Diyāb's "A Sultan of Samarcand."

Over centuries the dragon-killing-not-followed-by-a-wedding episode in the St. George religious legend became part of a secular fairy tale. That is a fact. That episode remained intact, despite its newly secular function in tales assigned to AaTh (now ATU) 301. That, too, is a fact. More often than not, the stuff of a religious legend changes significantly when it passes from the religious to the secular narrative sphere. That is a general observation. But in

53 In Tuite n.d.a. Tuite suggests a second source for the dragon-killing episode in the early eleventh-century Shahnameh. 
Hannā Diyāb's $A$ Sultan of Samarcand...

this case no shift took place. Something, evidently, caused the core episode to remain intact and unchanged.

Thinking through processes of narrative change and evolution, I conclude that the dragon-killing-not-followed-by-a-wedding episode remained unchanged at the core of the newly composed secular fairy tale, because the story shifted from the genre of religious legend to the genre of fairy tale within the cultural and religious community (Eastern Christianity in general and Greek Orthodoxy in particular) in which the religious legend remained alive and in circulation. Another way of saying this is that a stable institution, the church, propagated and maintained the St. George legend with St. George, the princess, the dragon, and no wedding. That stabilized the narrative, even when it migrated to a secular narrative environment. That core story must have been so well and so widely known within the community within which the new fairy tale was being composed, that it had to be taken into the new story in the form that people were familiar with. (Readers will recognize the process described here is opposite to that in novella creation in Western Europe in the late medieval and early modern period: novella creation meant telling a known story in an unknown and new way.) The unknown creator of the secular fairy tale seems to have embedded the known St. George legend within a framing fairy tale whose plot effectively explained why the dragon-killer did not marry the princess he had saved. That is, after all, precisely how the surrounding three-sisters-in-an-underground-realm fairy tale functions in the many nineteenth- and twentieth-century tales in Szövérffy's proposed sub-type 301C, and it is also how the same surrounding tale operates in the early eighteenth-century Diyāb's "A Sultan of Samarcand". His heroic prince Badi al-Zaman cannot marry the princess he saves from a dragon because he is already betrothed to Princess Fattane, when he encounters the dragon and the princess who has been set out for it to devour. Diyāb's prince must refuse the king's offer of the princess in marriage. (The unknown creator of the secular fairy tale did not complicate the story by adding in a forgotten bride.) Then follows the consequential and concluding sequel where a grateful rukh flies Badi al-Zaman to the world above, where he kills his treacherous brothers, and weds Princess Fattane.

My effort to account for the development of a tale that Joseph Szövérffy identified and defined as widespread in southwestern Asia and southeastern Europe in the $19^{\text {th }}$ and $20^{\text {th }}$ centuries and that Kevin Tuite records as still evident in the Caucasus, ${ }^{54}$ reveals something very important about Hannā

54 Tuite 2017: 21-56. 
Diyāb as a storyteller: he knew an Eastern Christian legend-based fairy tale in great detail. His deviations from the tale as later recorded were few. Hannā Diyāb may have encountered and learned this tale among Aleppan Christians, perhaps Maronites, but more likely among Aleppo's Greek Orthodox population of Eastern Christians. As pointed out by Bernard Heyberger, who has closely studied early modern Eastern Christianity, adherents of the two confessions often mixed in the late $17^{\text {th }}$ and early $18^{\text {th }}$ centuries in Aleppo. His own mother may, in fact, have come from a Greek Orthodox family.

This essay materially extends the reach of Hannā Diyāb's narrative repertoire. Beyond eighteenth-century Arabic or Garshūni popular literature and Jewish wisdom tales, Italian fairy tales translated into French, and Frenchlanguage fairyland fictions, ${ }^{55}$ Diyāb here participates in stories that had been generated within the Eastern Christianity of the Byzantine Empire and that continued to thrive in the religiously heterogeneous Ottoman Empire.

\section{Bibliography}

AARNE, Antti

1910 Verzeichnis der Märchentypen; mit Hülfe von Fachgenossen. Helsinki: Suomalainen Tiedeakatemia Toimituksia

AARNE, Antti - THOMPSON, Stith

[1928] 1961 The Types of the Folk-Tale: A Classification and Bibliography: Antti Aarne's Verzeichnis der Märchentypen (Folklore Fellow Communications 3). Helsinki: Suomalainen Tiedeakatemia

BAUDEN, Frédéric

2011 Esquisse biographique. In Galland, Antoine - Bauden, Frédéric (eds. et. al.): Le Journal d'Antoine Galland (1646-1715). La période Parisienne. Vol. 1. (1708-1709). 33-69. Liège: Peeters

BOLTE, Johannes - POLÍVKA, Georg

1913 Anmerkungen zu den Kinder- und Hausmärchen der Gebrüder Grimm. Vol. 2. Leipzig: Dieterich'sche Verlagsbuchhandlung

BOTTIGHEIMER, Ruth B.

n.d. Mme d'Aulnoy's 'White Cat,' Jean Gobi's Exemplum, and Lorenzo Selva's Allegory in Hanna Diyab's 'Prince Ahmed and Pari Banou'. [manuscript]

55 Bottigheimer n.d.; Bottigheimer 2020; Bottigheimer 2019; Bottigheimer 2014a; Bottigheimer 2014b: 60-61. 
Hannā Diyāb's $A$ Sultan of Samarcand...

2020 Hannā Diyāb, Antoine Galland, and Hannā Diyāb’s Tales: I. On-theSpot Recordings, Later Summaries, and One Translation; II. Western Sources in Eastern Texts. Mémoires. Association pour la Promotion de l'Histoire et de l'Archéologie Orientales. 51-72. Liège: Peeters

2019 Reading for Fun in Eighteenth-Century Aleppo. The Hannā Diyāb Tales of Galland's Mille et Une Nuits. Book History. 22. 133-160.

2014a The Case of The Ebony Horse. Part II. Hannā Diyāb's Creation of a Third Tradition. Gramarye. 6. 6-16.

2014b Magic Tales and Fairy Tale Magic from Ancient Egypt to the Italian Renaissance. Basingstoke: Palgrave Macmillan

BURTON, Richard F.

1885-1886 Book of A Thousand Nights and One Night. Vol. 1-10. London: Burton Club for Private Subscribers Only. Copy 737 of 1000.

1886-1888 Supplemental Nights to the Book of the Thousand Nights and a Night. Vol. 7. (subsequently Vol. 6.). London: Printed by the Burton Club for Private Subscribers only. Copy 737 of 1000.

CAMPBELL, Joseph

1949 Hero with a Thousand Faces. New York: Pantheon Press

CHILD, Francis James

1886 The English and Scottish Popular Ballads. Vol. 2. Boston: Houghton, Mifflin and Company

CODENHOTO, Christiane Damien

2007 Na senda das Noites: "Les quatre talismans" de Charles Nodier e "Les Mille et Une Nuits". Sao Paulo: University of Sao Paulo, Department of Oriental Literatures. Dissertation

GALLAND, Antoine

[1709] 2011 Bauden, Frédéric - Waller, Richard (eds.): Le Journal d'Antoine Galland (1646-1715). La période Parisienne. Vol. 1. (1708-1709). Liège: Peeters

GRIMM, Jacob - GRIMM, Wilhelm (eds.)

[1812, 1815] 1986 Rölleke, Heinz (ed.): Kinder-und Hausmärchen Gesammelt durch die Brïder Grimm. Vol. 2. Göttingen: Vandenhoeck \& Ruprecht

[1856, 1857] 1980 Rölleke, Heinz (ed.): Kinder- und Hausmärchen Gesammelt durch die Brüder Grimm. Vol. 3. Stuttgart: Reclam

von HAHN, Johann Georg

1864 Griechische und albanische Märchen. Vol. 2. Leipzig: Wilhelm Engelmann

MARZOLPH, Ulrich - DUGGAN Anne

2018a Hannā Diyāb’s Tales, Part 1. Marvels \& Tales. 32. 1. 133-154.

2018b Hannā Diyāb’s Tales, Part 2. Marvels \& Tales. 32. 2. 335-356.

MARZOLPH, Ulrich - VAN LEEUWEN Richard

2004 Three Princes and the Genius Morhagian and His Daughters, 417 Story of the (Burton from the Chavis manuscript). In Marzolph, Ulrich 
- Van Leeuwen, Richard: The Arabian Nights Encyclopedia. Vol. 1. 417. Clio: Santa Barbara CA

PUCHNER, Walter

2002 Prinzessinnen, Die drei geraubten P. (AaTh 301). In Lutz Rohrich (ed. et. al.): Enayyklopädie des Märchens. Vol. 10. 1363-1369. Berlin: De Gruyter

SZÖVÉRFFY, Joseph

1956 From Beowolf to the Arabian Nights (Preliminary notes on AarneThompson 301). Midwest Folklore. 6. 89-124.

THOMPSON, Stith

1932-1936 Motif-Index of Folk-Literature: A Classification of Narrative Elements in Folk-Tales, Ballads, Myths, Fables, Mediaeval Romances, Exempla, Fabliaux, Jest-Books, and Local Legends. Vol. 1-6. (Folklore Fellows Communications). Helsinki: Suomalainen Tiedeakatemia Bloomington Indiana: Indiana University Studies

TUITE, Kevin J.

n.d.a The Old Georgian Version of the Miracle of St. George, the Princess and the Dragon: [I] Text, Commentary and Translation https://www.academia.edu/42834443/The Old Georgian version o f_the_miracle_of_St_George the_princess_and_the_dragon_Part_I_ Text commentary and translation - April 6, 2021

n.d.b The Old Georgian Version of the Miracle of St. George, the Princess and the Dragon: II. Representations of George and his female counterpart in vernacular religion and folklore

2017 St. George in the Caucasus: Politics, Gender, Mobility. In Darieva, Tsypylma - Kahl, Thede - Toncheva, Svetoslava (eds.): Sakralität und Mobilität im Kankasus und in Südosteuropa. 21-56. Vienna: Verlag der Österreichen Akademie der Wissenschaften

UTHER, Hans-Jörg

2004a The Types of International Folktales. A Classification and Bibliography. Part 1. Animal tales, Tales of Magic, Religious Tales, and Realistic Tales, with an Introduction. Helsinki: Academia Scientiarum Fennica

2004b The Types of International Folktales. A Classification and Bibliography. Part 3. Appendices. Helsinki: Academia Scientiarum Fennica

ZIOLKOWSKI, Jan - BUSCHHAUSEN, Helmut

2002 In Memoriam Josef Szövérffy. In Smolak, Kurt (ed. et. al.): Wiener Humanistische Blätter Sonderbeft Hymnum Canamus Socii: In Memoriam Josef Szövérffy. 5. Wien: Wiener Humanistische Gesellschaft

ZOTENBERG, Hermann

1888 Histoire d'Alä al-Dìm, ou La lampe merveilleuses. Text arabe avec une notice sur quelques manuscrits des Mille et une nuits. Paris: Imprimerie Nationale 